\title{
The Differentiation and Promotion of Students' Rights in Portugal
}

\author{
FELICIANO VEIGA ${ }^{\mathrm{a}}$, FERNANDO GARCÍA $^{\mathrm{b}}$, FÉLIX NETO $^{c}$ \\ and LEANDRO ALMEIDA ${ }^{\mathrm{d}}$ \\ ${ }^{\mathrm{a}}$ University of Lisbon, Portugal, ${ }^{\mathrm{b}}$ University of Valencia, \\ Spain, 'University of Porto, Portugal and ${ }^{\mathrm{d} U n i v e r s i t y ~ o f ~ M i n h o, ~}$ \\ Portugal
}

\begin{abstract}
This investigation includes a differential study (Study 1) and a quasi-experimental research (Study 2). In Study 1, the objective was to establish to what extent students' rights existed and analyse the differentiation between students' rights with Portuguese and immigrant mothers, throughout school years. The sample consisted of 537 students with Portuguese and immigrant mothers, distributed by different school years (7th, 9th and 11th grades). The Children's Rights Scale (Hart et al., 1996; Veiga, 2001) was used. In Study 2, the purpose was to analyse the effects on students' rights of the use by teachers of a communicational intervention program, supervised by school psychologists. The sample involved 7 th and 9 th grade students, in a total of four classes, two forming the experimental groups $(n=36)$ and two the control groups $(n=43)$; as in Study 1, the Children's Rights Scale was used. The results indicated the effectiveness of the communicational intervention program on students' rights and are consistent with previous studies. An implication is that psychologists and teachers, working together and taking a human rights perspective, may develop an important role in projects to promote the students' rights.
\end{abstract}

KEY WORDS: human rights; immigration; interpersonal communication; students' rights

\section{Introduction}

Over 50 years after the approval of the Universal Declaration of Human Rights, on 10 December 1948, we still find situations of systematic transgressions of human rights. The 1948 Universal Declaration of Human Rights determines that 'All human beings are born free and equal in dignity and rights. They are endowed with reason and

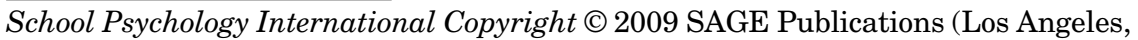
London, New Delhi, Singapore and Washington DC), Vol. 30(4): 421-436.

DOI: $10.1177 / 0143034309106947$ 
conscience and should act towards one another in a spirit of brotherhood' (Article 1). The approval of the Universal Declaration of Human Rights consigned the acknowledgement of the dignity all human beings 'without distinction of any kind, such as race, colour, sex, language, religion, political or other opinion, national or social origin, property, birth or other status'. However, violation of human rights continues to a large extent, particularly in war zones but also with regard to social minorities (Dunbar et al., 2007; Sparks, 1994; UNICEF, 1998; Ward and Birgden, 2007).

In 1989 conventions were adopted that not only refer to the right to protection and assistance, but also to freedom. Children must be protected against violence, brutality, maltreatment, cruel punishments; they should not be deprived of freedom in a fortuitous manner. Above all, children have the right to express themselves and give their opinion about the problems that concern them. The Convention on the Rights of the Child (UNICEF, 1998) states that 'the views of the child should be given due weight in accordance with the age and maturity of the child' (Article 12). One eminent function of education, hence of school, is to be at the service of the promotion of knowledge and of the practice of students' rights. Schools need to take a human rights perspective, preparing the students to think for themselves. School psychologists and teachers should be seeking 'to involve children at every opportunity in their own assessments and providing their own viewpoint on decisions that are made by others on their behalf' (Burden, 1993: 195). To paraphrase the words of Burden (1993: 197), 'taking a human rights perspective places working with children as a cornerstone of the practice' and seeks every opportunity 'to involve them in the decision-making process'. Thus, to valorize reflective learning and critical thinking are very important strategies.

Works and studies about human rights, particularly those concerning children and students, may be considered in multiple dimensions and complexities, such as their categorization in terms of differentiation and promotion of these same rights. Set within this perspective and considering the urgency of increasing interventions directed at promoting students' rights, we present two studies centred on teenagers at school. A differential study (Study 1) was carried out, the purpose of which was, on the one hand, to determine the extent of students' rights in school and, on the other, to analyse the differentiation between the rights of students with Portuguese and immigrant mothers, throughout the secondary school years. A quasi-experimental research design (Study 2) was also undertaken and aimed to investigate the effects of an intervention program, based on the Eclectic Communicational Model (ECM), on students' rights in school. 


\section{Human rights: some studies}

Currently human rights are looked upon as a nuclear social issue. The literature on the theme shows mostly studies of a differential nature and little quasi-experimental research. We will firstly present a brief summary of some differential studies. One study exists in Portuguese on citizenship rights (Benavente et al., 1997) and, focused on the right to education, there is another study (Monteiro, 1998), the main goal of which was to (re)think education in light of its quality as a right of man by developing the following topics: the evolution of the rights of man, the sources of the right to education, the ethics of the rights of man and of the right to education, and also the rights of man and the right to education in the Portuguese Constitution.

In a study carried out in Portugal (Veiga, 2001), as part of a crossnational research sponsored by UNESCO and coordinated by Hart et al. (2001), we analysed the representations of teenagers about the existence and importance of their rights in school and at home. The sample consisted of 294 students from the 7 th to the 9th grade, of both sexes and from different regions of the country. We used the Children's Rights Scale (CRS; Hart et al., 1996) as the evaluation instrument and asked questions about school, family and personal variables. As regards the school variables, analysis of the results showed significant relationships between the representations of rights and the above mentioned independent variables. Such relationships stress the need for changes in the school and family contexts in terms of giving more weight to human rights, particularly in sub-groups of subjects with worse living conditions. Significant correlations were observed between the existence of rights in school and students' achievement, as well as between the existence of rights and the absence of violent behaviour in school.

These results demonstrate the vital importance of rights, although their existence could still be broadened, especially in school. The subgroup of teenagers who had fallen behind saw themselves as having less rights at home and at school. Thus, the weakest students of the school appeared to have least rights, a fact that may contain a call for new and better forms of communicational interaction with those students. Teenagers with poorer school achievement were also found to be aware of having less rights at school, and particularly at home, and this concerned several dimensions of rights. Perhaps the promotion of cognitive competences is connected to the development of the ability for assertive affirmation in obtaining these rights, or else better performance at school provides easier access to the same rights. Such data may show the need to facilitate the relationship between weaker and stronger students, highlighting the idea that all have the right to a sound human development; on the other hand, stimulating school 
achievement, with the involvement of teachers and parents, seems to constitute a good route to promote the importance and existence of teenagers' rights. These data identified teachers' support as one of the ways to increase teenagers' rights at school and at home. Such support was related to every dimension of the rights, particularly to esteem and self-determination, corroborating the importance of personal valorization proposed by many studies (Burden, 1993; 1998; Dunbar et al., 2007; UNICEF, 1998; Veiga, 2004; Ward and Birgden, 2007).

In an exploratory study with a sample formed by 318 subjects from different school years (7th, 9th and 11th grades) from schools in Greater Lisbon (Veiga and Melo, 2005), we found a striking presence of rights in school, with significant differences in the dimensions of these rights according to the school year but not to nationality. These differences favoured the younger groups. They also revealed the absence of an interaction effect of the variables school year and nationality.

The study coordinated by Hart et al. (2001) on the existence and importance of teenagers' rights in the school and in the family, within the scope of a cross-national study with 23 countries including Portugal, acquired great prominence (Hart et al., 2001; Irving 2001; Jacobsen and Schlegel; 2001; Pavlovic, 2001; Tereseviciene and Jonyniene, 2001; Veiga, 2001). This study also points out the rights that are less present (such as the right to imagination, i.e. 'To have a place and time to be alone, without being disturbed by others') and suggests the need for further studies, for new evaluation instruments to be elaborated and for urgency in implementing and promoting human rights on the world.

Apart from these studies, scientific research is lacking in specific investigations about teenagers' perception of the evolution of their rights, in different contexts and throughout their lives. We observe a significant lack of studies of a quasi-experimental nature directed towards the promotion of human rights (Symonides, 2000; UNESCO, 1998; Ward and Birgden, 2007). One of the few studies of this nature examined the effect on students' rights of an intervention program based on a humanistic relational model, during approximately 14 school weeks (Veiga, 1999); this study highlighted benefits for the students in the experimental groups in that their rights in relational dimensions increased.

\section{Immigration and human rights}

The history of humankind can also be looked upon as the history of migrations (Sen and Koray, 2000; UNICEF, 1998). In Portuguese schools, the growing percentage of students with immigrant parents is often mentioned by teachers and by reports on immigration. The social 
situation has been the object of several studies that stress factors such as internal differentiation, modes of politicizing (Machado, 1997) and precariousness of living conditions (Bruto da Costa and Pimenta, 1991).

Protection standards for immigrants are far from consensual (Sen and Koray, 2000). Take, for instance, the International Convention on the Protection of the Rights of All Migrant Workers and the difficulties it encounters in terms of realization. The European Social Letter of the European Council has also proved to be an important instrument for defending immigrants' rights and the International Labour Organization (ILO) has contributed greatly to the protection of immigrant workers' rights (Sen and Koray, 2000).

In Portugal, a study by Bruto da Costa and Pimenta (1991) has shown that children with immigrant parents, even those born in Portugal, have high rates of underachievement in school and less future opportunities for socio-professional integration. However, we cannot generalize young immigrants' issues because, despite certain common problems, there are also differences among immigrants coming from different countries. An example of this is a study by Neto (1995), who found significant differences between Portuguese and Angolan teenagers in terms of the satisfaction they felt with their lives, but did not find the same when comparing the Portuguese to Cape-Verdeans or to Indians.

Teachers can act as key figures in promoting intercultural education by implementing strategies that foster the establishment of productive inter-ethnic relations; the promotion of human rights should be assumed as an urgent goal, as a necessary condition for one's full development (Burden, 1998; García et al., 2006; Symonides, 2000; Ward and Birgden, 2007). These ideas underpin the studies that we present here.

\section{Studies carried out}

Before specifying the methodology followed in each study, we present the formulation of the general aim and the questions to be considered. The main aim was to find answers to the following general problems: What are the variations in students' rights in Portuguese schools? From these general problems, the following general questions arose:

- What is the relationship between rights and other variables pertaining to social and school contexts (nationality and school year)?

- What are the effects of intervention with the Eclectic Communicational Model on the variation of rights and the variables related to them?

These general questions are part of two specific studies that were 
carried out; a differential study (Study 1) and a quasi-experimental research (Study 2), which we will now describe.

\section{Differential study}

The general aim of this study was to establish to what extent students' rights in school existed and to analyse the differentiation between students' rights of those with Portuguese and immigrant mothers. The mothers' nationality - Portuguese versus immigrant to Portugal from 'African Countries with Portuguese as their Official Language' (ACPOL) - and school year were considered as independent variables. The following specific questions were elaborated:

- To what extent is the existence of rights in school recognized by students with Portuguese and immigrant mothers?

- Is there a significant difference in students' perceived rights according to mothers' nationality? How do these rights change over the schooling years?

- Does a main effect or an interaction effect of the independent variables (school year and nationality) occur in the establishment of students' rights?

\section{Procedure}

After requesting permission, questionnaires (see below) were applied to the students, who were supervised by their class teachers as they completed them. This task took place during regular school hours with the voluntary collaboration of these students, who made themselves available for as long as necessary. This study was based on an extension of a previous exploratory study (Veiga and Melo, 2005).

\section{Instruments}

We used the Children's Rights Scale (CRS) evaluation instrument (Hart et al., 1996), after changing it by grouping the items into specific factors (Veiga, 2001): basic provision, protection-security, socialemotional relationship, recognition-esteem, educational instruction and self-determination. The adaptation of the instrument also included changing the Likert-type scale, from 1-5 to from 1-6 (from 'never present' to 'always present'). A previous study (Veiga, 2001) presents high Cronbach's alpha for dimensions of the CRS, with 0.90 in the total scale.

\section{Subjects}

The sample consisted of 537 subjects distributed across different school years (7th, 9th and 11th grades), including subjects of both genders and 
Table 1 Group of three rights that are most and least present in immigrant and not immigrant students

Items

Means

Portuguese: Most present

20 (RE) To have your own special name from birth

13 (SE) To have the opportunity to have good friends

05 (SE) To be a good friend to others

Portuguese: Least present

34 (PS) To be protected from people and situations which might hurt your feelings

23 (SD) To have money to spend as you choose

21 (BP) To have time and a place to be alone without being bothered by others

Immigrants: Most present

13 (SE) To have the opportunity to have good friends

20 (RE) To have your own special name from birth

05 (SE) To be a good friend to others

Immigrants: Least present

21 (BP) To have time and a place to be alone without being bothered by others

04 (PS) To be treated fairly when people think you are wrong

23 (SD) To have money to spend as you choose

$\mathrm{BP}=$ basic provision $; \mathrm{EI}=$ educational instruction; $\mathrm{PS}=$ protection-security $; \mathrm{RE}=$ recognition-esteem; $\mathrm{SD}=$ self-determination; $\mathrm{SE}=$ social-emotional relationship.

from different regions of Portugal (Lisbon, North, South and Islands). Considering the students by mothers' nationality, the division was 80.12 percent Portuguese and 19.88 percent immigrant to Portugal from Africa (ACPOL). Although we also gathered the students' and fathers' nationalities, in order to maximize the analyses without possible statistical bias, the results we present here were considered only according to the nationality of the students' mothers.

\section{Results}

Table 1 shows the three rights that were attributed as being least and most present in school. Those considered least present are rights located in self-determination (item 23) and in provision (item 21), in both students with Portuguese and immigrant mothers; among the least present rights are item 34, 'To be protected from people and situations which might hurt yours feelings' in the Portuguese sub-group and item 4 , 'To be treated fairly when people think you are wrong', both 
Table 2 Number of subjects (n), means and SD of the results in the CRS, according to school year (grade), with t values and significance to various contrasts

\begin{tabular}{lrrrrrrr}
\hline CRS / Grade & $\mathrm{n}$ & Means & SD & Contrast & $\mathrm{t}$ & \multicolumn{2}{c}{ Sig } \\
\hline Instruction & $7^{\circ}$ & 201 & 38.6468 & 6.51764 & $7^{\circ}>9^{\circ}$ & 2.112 & $* *$ \\
& $9^{\circ}$ & 148 & 37.1351 & 7.18715 & $7^{\circ}>11^{\circ}$ & 2.187 & $* *$ \\
Protection & $11^{\circ}$ & 188 & 37.1809 & 6.21618 & $9^{\circ}=11^{\circ}$ & -0.065 & $\mathrm{~ns}$ \\
& $7^{\circ}$ & 183 & 43.8306 & 8.16578 & $7^{\circ}>9^{\circ}$ & 2.470 & $* *$ \\
& $9^{\circ}$ & 141 & 41.6170 & 8.25111 & $7^{\circ}=11^{\circ}$ & 1.046 & $\mathrm{~ns}$ \\
Provision & $11^{\circ}$ & 178 & 42.9494 & 7.61227 & $9^{\circ}=11^{\circ}$ & -1.478 & $\mathrm{~ns}$ \\
& $7^{\circ}$ & 205 & 23.3366 & 5.01751 & $7^{\circ}>9^{\circ}$ & 2.716 & $* * *$ \\
& $9^{\circ}$ & 145 & 21.9448 & 4.86595 & $7^{\circ}>11^{\circ}$ & 3.740 & $* * *$ \\
& $11^{\circ}$ & 187 & 21.5508 & 4.25167 & $9^{\circ}=11^{\circ}$ & 0.754 & $\mathrm{~ns}$ \\
\hline
\end{tabular}

$* * p<0.01 ; * * * p<0.001 ; \mathrm{ns}=$ not significant.

located in the protection-security dimension. The most present rights are found in the relationship dimension (items 5 and 13) and in the recognition dimension (item 20), regardless of background. We also found that the least present rights emerged (on the temporality scale of 1 to 6 ) between the parameter 'present few times' (3) and the parameter 'often present' (4). The rights that were most present were in the parameter 'almost always present' (5). The mean scale CRS of the 40 items is 4.48 and is located between the parameter 'often present' (4) and the parameter 'almost always present' (5).

To find out how rights change throughout adolescence we carried out analyses to check whether there were significant differences in the dimensions of the rights according to the school year. In Table 2 we show the relevant results obtained. Regarding provision, there is a significant reduction from the 7 th to the 9 th grade $(t=2.716 ; \mathrm{Gl}=348$; $p<0.001$ ), but no significant change from the 9 th to the 11 th grade. We find a similar pattern with respect to the instruction dimension, although the statistical significances are smaller. In the area of protection, there is a reduction from the 7th to the 9th grade. In the remaining dimensions of the rights (relationship, recognition and selfdetermination), we recorded no significant differences in the total sample throughout the school years.

Besides studying variations in the presence of rights according to school years, we were also interested in analysing the interaction of the variables school year and ethnic background. In most situations we found no statistically significant differences in their assumed rights between Portuguese students and ACPOL students, whether they were in the 7 th, 9 th or 11 th grades. 


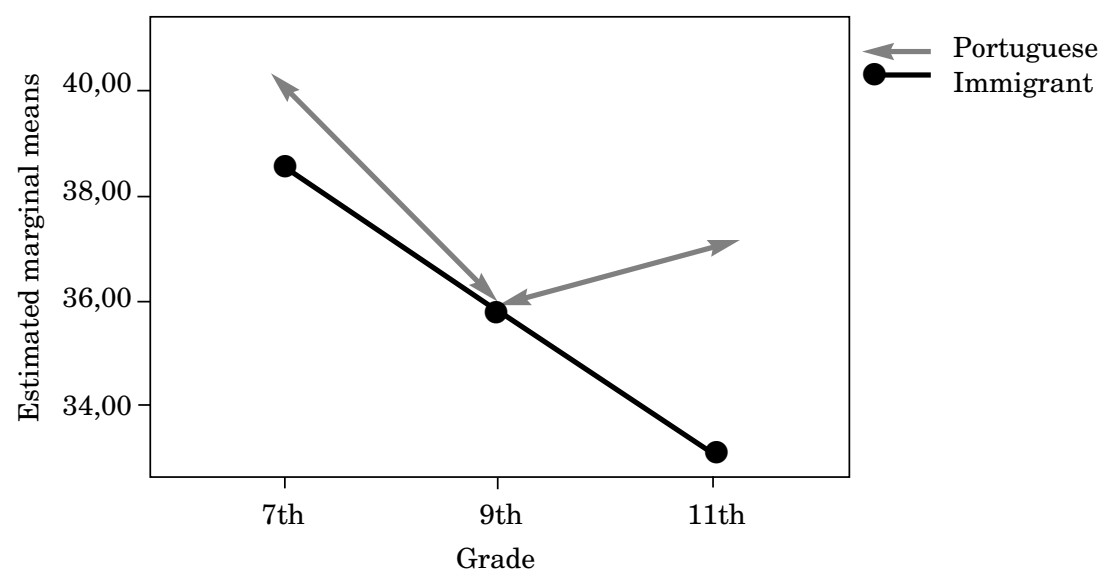

Figure 1 Mean scores in educational instruction, according to grade and mothers' nationality

The data regarding instruction, shown in Figure 1, deserve some consideration. In the Portuguese group we find a statistically significant reduction from the 7th to the 9th grade and no significant change from the 9 th to the 11th grade, which corroborates the data obtained in the total sample. Both in the 7th and in the 9th grades, contrasts between ethnic groups were not significant, but in the 11th grade they were $(p<0.01)$. In short, we found a reduction of rights from the 7 th to the 9th grade, then a stabilization from the 9 th to the 11th grade in students with Portuguese mothers and a continuation of the reduction in students with immigrant mothers. Later analyses controlling the level of family instruction revealed that results maintained the parameters that were described.

\section{Discussion}

Regardless of nationality, students in Portugal recognize that nowadays their rights exist in school. However, the existence of these rights is less manifest in aspects related to self-determination, as well as to protection and to provision. We observed that both in students with Portuguese and immigrant mothers those rights that were least present emerged between the parameter 'present few times' and the parameter 'often present', while those that were most present were located in the parameter 'almost always present'. As far as students in general are concerned, these results match previous studies (Dunbar et al., 2007; Hart et al., 2001; Veiga, 2001; Veiga and Melo, 2005). The 
non-differentiation between students with Portuguese and immigrant mothers is similar to a study that found no differences in terms of intimacy or love between these subjects (Pinto, 2005) and to another study that found no significant differences regarding satisfaction with life between Portuguese and Indian or Cape-Verdean teenagers (Neto, 1995).

It is likely that these results indicate Portuguese students' general acceptance of students who are the offspring of immigrants. The socializing role of school and the internalization of the values it conveys may also justify the non-discrimination we observed. From a less optimistic perspective, it may be that another explanation is the hypothesis of a hyper-evaluation of the existence of rights by immigrant offspring, due to the lesser importance they attribute to rights in school, in comparison to Portuguese students. This explanation, which we suggested in a previous study (Veiga and Melo, 2005), finds an expected consistency here, for the data gathered regarding the right to instruction showed that there was a significant differentiation between students with Portuguese and immigrant mothers in the 11th grade, but none in the 7 th or 9th grades. The explanation for such results could be that 11th grade students with immigrant mothers value school more than their peers, also born of immigrant mothers, who abandon it, and therefore they would attribute more importance to the right to instruction, given their perception of a weaker presence of such rights than that of students with Portuguese mothers, also attending the 11th grade. We suggest that in further studies the CRS scale is applied, asking students about the existence and, simultaneously, the importance attributed to each right and analysing the correlation between these variables in students with Portuguese and immigrant mothers.

As regards the school year, 9th grade students, when compared to those in the 7th grade, perceive the existence of less rights in school (provision, protection and instruction), while no differences were found between the 9 th and the 11th grades. These results are in line with those observed in previous studies (Veiga, 2004; Veiga and Melo, 2005). Perhaps advancing towards the end of compulsory schooling (9th grade) increases the general demands on such individuals and they start perceiving more obstacles in the path of realizing these rights; it may also happen that a greater need of affirmation in older subjects (Erikson, 1980) contributes to the importance attributed to rights greater in older than in younger subjects - and probably hence the perception of a weaker existence of these same rights in older students. Maintenance of these elements (need of affirmation, demands made and importance of rights) between the 9 th and the 11th grades would contribute to explain the non-differentiation of rights between students attending these years, along with school contexts of the same type. 


\section{Quasi-experimental research with the Eclectic Communicational Model}

The objective of this quasi-experimental research was to analyse the effects on students' rights of the use by teachers of an intervention program, with the Eclectic Communicational Model described in a previous study (Veiga, 1999). The importance of interpersonal communication has been stressed by many investigations (Veiga, 1999, 2004). One could say that without communication there is no human relationship and without relationship there is no education. The Eclectic Communicational Model adopts a perspective centred on interpersonal communication and can be used in the promotion of human rights. This model is constituted by several communicational categories, some working as obstacles to the human relationship, others integrating a humanitarian perspective and emerging as essential competences for the promotion of education in general and human rights in particular.

Besides these dimensions, the program also included the following communicational competences: active listening (attention and kindness); self-revelation and authenticity; feedback; confrontation; communicational consistency; self-control and cooperation. Their training led to the creation of a general action plan to guide the way teachers organized their classes, based on the following ideas: preferential and principal use of communicational competences in their relationship with students; use of school contents and daily life situations to reflect upon human rights; stimulation of cooperative learning; involving students in the decision-making process; valorizing active and reflective learning and promoting critical thinking. Specifically, the aim of this quasi-experimental research (Study 2) was to find answers to the following specific questions:

- Can student's rights with Portuguese and immigrant mothers be promoted through specific teacher education actions, supervised by school psychologists?

- Which dimensions of rights in school can benefit the most from an intervention with the Eclectic Communicational Model?

\section{Procedure}

This investigation-action project had two phases: training teachers in $E C M$ - an initial seminar supervised by educational and school psychologists and further meetings for reflection and planning; intervention in experimental classes - with the support of school psychologists, meetings to analyse and discuss cases, sharing experiences to respond to students' specific needs and possible reformulation of strategies. The Eclectic Communicational Intervention was applied to the experimental group, while the control group continued to have 
the same teacher-student relationship it had known so far. The intervention took place in two Lisbon schools, lasted for about 18 weeks of classes and began after the Christmas holidays.

\section{Instruments}

As in Study 1, we also used here the CRS that was applied before and after carrying out the experiment (intervention).

\section{Subjects}

This Study involved 7 th $(n=37)$ and 9 th grade students $(n=42)$, in a total of four classes, two forming the experimental group $(n=36)$ and two the control group $(n=43)$. The groups were considered equivalent in the pre-test situation.

\section{Results}

Table 3 shows the differences between mean scores on the CRS, in the pre-test and post-test situations, for the control group (CG) and for the experimental group (EG), in the 7th grade. Only two dimensions of the rights revealed no variation: self-determination and instruction. The remainder showed highly significant improvements $(p<0.001)$. Elements regarding the 9th grade are also presented in Table 3; four of the six dimensions of the rights showed no variation with the intervention, namely self-determination, instruction, protection and provision. Between the pre-test and post-test situations, and regarding socioemotional relationships and recognition-esteem, the results point out the existence of significant differences in the experimental group, though on the threshold of statistical significance $(p<0.05)$, while the control group had no such differences.

In the analyses carried out, the differences between the control group and the experimental group went from being non-significant, in the pre-test situation, to statistically significant and favourable for the experimental group in the post-test situation. Complementary analyses showed that the results obtained by the students were not conditioned by mothers' nationality.

\section{Discussion}

One finding was a greater efficacy of the intervention with 7th grade students than with those in the 9th grade; this superiority probably has to do with age, that is, with the reduction of educational changeability with age, a fact that seems understandable in the context of the theories of psychological development (Dunbar et al., 2007; Pinto, 2005; Veiga, 2004). The results obtained here are consistent with previous studies (Veiga, 1999, 2004). 
Table 3 Number of subjects (n), means and SD of the results in the CRS dimensions, in pre-test and post-test situations for the control group (CG) and experimental group (EG) in the 7th and 9th grades, with $\mathrm{t}$-values and significance to contrasts

\begin{tabular}{|c|c|c|c|c|c|c|c|c|c|}
\hline \multirow[b]{2}{*}{ Grades } & \multirow[b]{2}{*}{ Dimensions } & \multirow[b]{2}{*}{ Group } & \multirow[b]{2}{*}{$\mathrm{N}$} & \multicolumn{2}{|c|}{ Pre-test } & \multicolumn{2}{|c|}{ Post-test } & \multirow[b]{2}{*}{$\mathrm{t}$} & \multirow[b]{2}{*}{ Sig. } \\
\hline & & & & Means & $S D$ & Mean & $S D$ & & \\
\hline \multirow[t]{8}{*}{7 th } & \multirow[t]{2}{*}{ Esteem } & CG & 20 & 11.3 & 2.1 & 11.4 & 1.9 & -0.1 & $\mathrm{~ns}$ \\
\hline & & EG & 17 & 11.6 & 1.8 & 13.2 & 1.5 & -2.8 & $* * *$ \\
\hline & \multirow[t]{2}{*}{ Relationship } & CG & 20 & 24.2 & 3.7 & 25.7 & 3.0 & -1.3 & $\mathrm{~ns}$ \\
\hline & & EG & 17 & 24.2 & 3.1 & 27.6 & 3.5 & -3.0 & $* * *$ \\
\hline & \multirow[t]{2}{*}{ Protection } & CG & 20 & 36.1 & 5.9 & 35.9 & 5.3 & 0.1 & $\mathrm{~ns}$ \\
\hline & & EG & 17 & 34.4 & 5.3 & 38.7 & 5.6 & -2.4 & $* *$ \\
\hline & \multirow[t]{2}{*}{ Provision } & CG & 20 & 19.1 & 3.3 & 19.5 & 3.6 & -0.4 & $\mathrm{~ns}$ \\
\hline & & EG & 17 & 19.4 & 3.0 & 22.8 & 3.1 & -3.5 & $*$ \\
\hline \multirow[t]{4}{*}{ 9th } & \multirow[t]{2}{*}{ Esteem } & CG & 23 & 11.1 & 3.1 & 11.9 & 1.9 & -1.1 & $\mathrm{~ns}$ \\
\hline & & EG & 19 & 11.5 & 2.5 & 13.0 & 2.2 & -1.9 & $*$ \\
\hline & \multirow[t]{2}{*}{ Relationship } & CG & 23 & 23.7 & 3.0 & 24.9 & 3.4 & -1.3 & $\mathrm{~ns}$ \\
\hline & & EG & 19 & 24.0 & 2.8 & 25.5 & 2.3 & -1.8 & $*$ \\
\hline
\end{tabular}

$* p<0.05 ; * * p<0.01 ; * * *<<0.001 ;$ ns $=$ not significant.

\section{Final remarks}

As regards the differential study, the results match those obtained in previous researches (Hart et al., 2001; Veiga 1999, 2001; Veiga and Melo, 2005; Ward and Birgden, 2007). One of the educational implications is that teachers have the duty to promote students' rights, but at the same time they must teach them their duties regarding the rights and duties of others: rights and duties are inter-related in every social activity of man. A critical and interventionist conscience is urgent in the promotion of everyone' rights, but above all of those who are weakest (Burden, 1993; UNICEF, 1998; Ward and Birgden, 2007).

With respect to Study 2 , besides the improvement in rights perceived by students, regardless of mothers' nationality, other observations reflect the positive effect of the Eclectic Communicational Model, in aspects such as a greater reflection, a reduction of disruptive behaviour and an increase in students' satisfaction with school. Further investigations could consider as their object of study the possible effect of teacher education in communicational models, such as ECM, on the professional development of the teachers. An important implication is that school psychologists and teachers must take a human rights perspective (Burden, 1993; Veiga, 1999; Ward and Birgden, 2007).

Globally, from the information we gathered, we conclude that there is a need for differential and interventional studies on human rights, 
valuing school psychologists' action with teachers in a connection between school and the family. The ecological model of human development (Bronfenbrenner, 1986; Dunbar et al., 2007; García et al., 2006; UNICEF, 1998) can be used as a theoretical frame for these new studies. We believe that new rights are emerging, which require specific educational training and new developments (Symonides, 2000; UNESCO, 1998; Ward and Birgden, 2007).

Instead of treating human rights as a simple content in the curriculum, it is important to change everyday life in school into a space of reflexive action, ethical companionship and education for peace. Schools must prepare children to deal with change. The United Nations Convention on the Rights of the Child emphasizes the purpose of education in the development of respect for human rights and fundamental freedoms. We have a responsibility as psychologists to help teachers, parents and students to find ways of making them a reality. Calling for the defence of rights is about helping to build a society where the wellbeing, the respect for differences and the equality of opportunities become real (Burden, 1993; Sen and Koray, 2000; UNICEF, 1998; Veiga, 2004; Ward and Birgden, 2007). The future of the world depends, in the first place, on today's children and students; thus, they must know their rights and duties, as part of their full education as persons. Not only on a cognitive level but also on a level of feeling and affection, the internalization of rights by themselves and by the community is a fundamental path towards the consolidation of the rights of others and must necessarily embrace the duties of everybody.

\section{Note}

This study was financed by the Foundation for Science and Technology (FCT).

\section{References}

Benavente, A., Mendes, H. and Schmidt, L. (1997) 'Direitos dos Cidadãos em Portugal: Conhecimentos e Opiniões', Sociologia - Problemas e Práticas 24: 71-114.

Bronfenbrenner, U. (1986) 'Ecological Systems Theory', in R. Vasta (ed.) Annals of Child Development, 6, pp. 187-251. Greenwich. CT: Jai.

Bruto da Costa, A. and Pimenta, M. (1991) Minorias Étnicas Pobres em Lisboa. Lisboa: Departamento de Pesquisa Social do Centro de Reflexão Cristã.

Burden, R. (1993) 'Taking a Human Rights Perspective: Some Basic Implications for the Practicing School Psychologist', School Psychology International 14: 195-98.

Burden, R. (1998) 'Assessing Children's Perceptions of Themselves as Learners and Problem-Solvers: The Construction of the Myself-as-Learner Scale', School Psychology International 19(4): 291-305.

Dunbar, E., Sullaway, M., Blanco, A., Horcajo, J. and Corte, L. (2007) 'Human 


\section{Veiga et al.: Students' Rights in Portugal}

Rights Attitudes and Peer Influence: The Role of Explicit Bias, Gender, and Salience', International Journal of Intercultural Relations 31(1): 51-66.

Erikson, E. H. (1980) Identity and the Life Cycle, 2nd edn. New York: Norton.

García, J. F., Musitu, G. and Veiga, F. H. (2006) 'Self-Concept in Adults from Spain and Portugal', Psicothema 18(3): 551-56.

Hart, S. N., Pavlovic, Z. and Zeidner, M. (2001) 'The ISPA Cross-National Children's Rights Research Project', School Psychology International 22(2): 99-129.

Hart, S. N., Zneider, M. and Pavlovic, Z. (1996) 'Children's Rights: Cross National Research on Perspectives of Children and their Teachers', in M. John (ed.) Children in Charge: The Child Right to a Fair Hearing, pp. 38-58. London: Jessica Kingsley Publishers.

Irving, K. (2001) 'Australian Students' Perceptions of the Importance and Existence of their Rights', School Psychology International 22(2): 224-40.

Jacobsen, E. and Schlegel, I. (2001) 'Students' Perceptions of their Rights in Denmark', School Psychology International 22(2): 174-89.

Machado, F. (1997) 'Contornos e Especificidades da Imigração em Portugal', Sociologia, Problemas e Práticas 24: 9-44.

Monteiro, A. R. (1998) O Direito à Educação. Lisboa: Livros Horizonte.

Neto, F. (1995) 'Predictors of Satisfaction with Life Among Second Generation Migrants', Social Indicators Research 35: 93-116.

Pavlovic, Z. (2001) 'Cross-Cultural Study on the Rights of the Child in Slovenia: The First Ten Years', School Psychology International 22(2): 130-51.

Pinto, M. C. P. (2005) Intimidade em Adolescentes de Diferentes Grupos Étnico. Lisboa: Universidade Aberta.

Sen, F. and Koray, S. (2000) 'Migrant Workers' Rights', in J. Symonides (ed.) Human Rights: Concept and Standards, pp. 327-41. Paris: Ashgate and UNESCO.

Sparks, E. (1994) 'Human Rights Violations in the Inner City: Implications for Moral Educators', Journal of Moral Education 23(3): 315-32.

Symonides, J. (2000) Human Rights: Concept and Standards. Paris: UNESCO.

Tereseviciene, M. and Jonyniene, Z. (2001) 'Students' Perceptions of Their Rights in Lithuania', School Psychology International 22(2): 152-73.

UNESCO (1998) Taking Action for Human Rights in the Twenty-First Century. Paris: UNESCO.

UNICEF (1998) The Proposed UN Convention on the Rights of the Child. New York: UNICEF.

Veiga, F. H. (1999) Indisciplina e Violência na Escola: Práticas Comunicacionais para Professores e Pais. Coimbra: Almedina.

Veiga, F. H. (2001) 'Students' Perceptions of their Rights in Portugal', School Psychology International 22(2): 174-89.

Veiga, F. H. (2004) 'Promotion of Rights and Behavioural Adequacy of Students in School: Effects of a Transactional Analysis Programme', Communication presented in 'XXVth International School Psychology Colloquium - News: School Psychology: Whose Needs? Whose Benefit', Exeter, 27-31 July 2004.

Veiga, F. H. and Melo, C. (2005) 'Direitos dos Alunos, em Função da Escolaridade e da Nacionalidade, ao longo da Adolescência', Communication presented in VIII Congresso da Sociedade Portuguesa de Ciências da Educação (SPCE). Castelo Branco: Instituto Politécnico.

Ward, T. and Birgden, A. (2007) 'Human Rights and Correctional Clinical Practice', Aggression and Violent Behavior 12(6): 628-43. 
Feliciano H. Veiga, $\mathrm{PhD}$, is a Professor of Educational Psychology at the University of Lisbon. His research interests include educational psychology, self-concept, violence in schools and children's rights. Address: Department of Education and Center for Research in Education, University of Lisbon, Faculty of Sciences, R. Ernesto Vasconcelos, Edif. C6-2º, 1749-016, Lisbon, Portugal. Email: fhveiga@fc.ul.pt

Fernando García, PhD, is a Professor of Psychological Methods and designer of research studies. Address: Department of Methodology of the Behavioral Sciences, Faculty of Psychology, University of Valencia, Avd. Blasco Ibanez, 21, 46010, Valencia, Spain.

Félix Neto, $\mathrm{PhD}$, is a Professor of Social Psychology at the University of Porto. Address: Faculdade de Psicologia e de Ciências da Educação, Universidade do Porto, Rua Dr. Manuel Pereira da Silva, 4200-392 Porto, Portugal.

Leandro S. Almeida, PhD, is a Professor of Educational Psychology at Minho University. Address: Institute of Education and Psychology, University of Minho, Campus de Gualtar, 4710 Braga, Portugal. 